\title{
Lack of association between PAX6/ SOSTDC1/FAM2OB gene polymorphisms and mesiodens
}

Shanshan Liu, Jiancheng Li, Jincheng Xu, Shengkai Liao, Yongfeng Chen, Rongxiu Zhang, Ruixue Tian and Kai Zhang ${ }^{*}$ (D)

\begin{abstract}
Background: The purpose of this study was to analyze the association between the genetic polymorphism of genes (PAX6, SOSTDC1and FAM2OB) and the susceptibility to mesiodens.

Methods: This study was carried out on 50 patients with mesiodens and 50 controls. The family history of each patient with mesiodens were recorded. Genomic DNA was extracted from saliva samples, and single nucleotide polymorphisms were detected in all exons and exon/intron boundaries of PAX6, SOSTDC1 and FAM2OB using Sanger sequencing. The data were analyzed using pearson chi-square test with theoretical frequency $\geq 5$. For theoretical frequency less than 5 but at least $1(\leq 20 \%$ cell), the data were analyzed by continuity correction. For the rest, Fisher's Exact test was used. A $P$-value $<0.05$ was considered statistically significant. The Odds ratio (OR) and confidence intervals (Cl) were recorded.

Results: Three polymorphisms were detected in PAX6. Two polymorphisms were detected in SOSTDC1. Twenty-nine polymorphisms were detected in FAM20B. Although, the T allele of FAM2OB (rs3766626) appears to be associated with mesiodens $(P=0.051)$, there were no significant differences of PAX6/SOSTDC1/FAM2OB gene polymorphisms between the two groups. The T allele of FAM2OB (rs3766626) was associated with susceptibility to two mesiodens $(P<0.001$; $\mathrm{OR}=8.333 ; \mathrm{Cl}=2.516-27.600)$.

Conclusions: Lack of association between PAX6/SOSTDC1/FAM2OB gene polymorphisms and mesiodens in the population studied was detected. Further studies with large samples on T allele of FAM2OB (rs3766626) are needed.
\end{abstract}

Keywords: Mesiodens, PAX6, SOSTDC1, FAM20B, Genetic polymorphism

\section{Background}

Mesiodens is the most common supernumerary teeth located in the central position of the upper or lower jaw [1]. Mesiodens can be either erupted or impacted in alveolar bone placed and oriented vertically, horizontally or in an inverted manner [2,3]. The prevalence of mesiodens in the population ranges from 0.09 to $2.2 \%$, according to previous studies [4-6]. A series of clinical complications can be caused by mesiodens, including malposition or delayed eruption of the permanent incisors or the formation of a dentigerous cyst [7-9]. However, the etiology of mesiodens is still unclear.

\footnotetext{
* Correspondence: zhangkai29788@163.com

Department of Stomatology, The First Affiliated Hospital of Bengbu Medical College, 287 Chang Huai Road, Bengbu 233004, China
}

An increasing number of studies indicate that genetic polymorphisms are associated with oral diseases. For instance, in Polish children, the prevalence of the AG genotype of the Enamelin (ENAM) gene (rs12640848) was higher in subjects with dental caries compared to that in controls [10]. The polymorphism of COX2 $-765 \mathrm{G} / \mathrm{C}$ had significant influence on periodontitis risk [11]. The genetic polymorphism of axin 2 (AXIN2) and Gremiln-2 (GREM2, also called PRDC) were related with tooth agenesis [12, 13].

Studies have shown that several genes can result in the formation of mesiodens. The Paired box gene 6 (PAX6) mutant in rats can result in the formation of a supernumerary upper incisor [14]. The inactivation of Family with sequence similarity member $20-\mathrm{B}(F A M 20 B)$ in the

(c) The Author(s). 2019 Open Access This article is distributed under the terms of the Creative Commons Attribution 4.0 International License (http://creativecommons.org/licenses/by/4.0/), which permits unrestricted use, distribution, and reproduction in any medium, provided you give appropriate credit to the original author(s) and the source, provide a link to the Creative Commons license, and indicate if changes were made. The Creative Commons Public Domain Dedication waiver (http://creativecommons.org/publicdomain/zero/1.0/) applies to the data made available in this article, unless otherwise stated. 
Table 1 Amplification and sequencing primers

\begin{tabular}{|c|c|c|c|}
\hline ID & Primer sequences & Amplicon size (bp) & Sequencing size (bp) \\
\hline PAX6 exon-1 $\mathrm{F}$ & CAAACGGACCAATTGCACCA & \multirow[t]{2}{*}{432} & \multirow[t]{2}{*}{432} \\
\hline PAX6 exon-1 R & GGTTGGTGTGTGAGAGCAATTCTC & & \\
\hline PAX6 exon-2 F & CAGAGGTCAGGCTTCGCTAA & \multirow[t]{2}{*}{449} & \multirow[t]{2}{*}{449} \\
\hline PAX6 exon-2 R & TCGCTGGAAGTAGAAAGTTTGG & & \\
\hline PAX6 exon-3 F & TGACTGAGCCCTAGATGCATGTG & \multirow[t]{2}{*}{466} & \multirow[t]{2}{*}{466} \\
\hline PAX6 exon-3 R & TCCCCAATCTGTTTCCCCTACAT & & \\
\hline PAX6 exon-4 F & GAACGGAGATTCTCCTGTCCTA & \multirow[t]{2}{*}{364} & \multirow[t]{2}{*}{364} \\
\hline PAX6 exon-4 R & CAGTATCGAGAAGAGCCAAGC & & \\
\hline PAX6 exon-5 F & AGGATGCATTGTGGTTGTCTCCTC & \multirow[t]{2}{*}{405} & \multirow[t]{2}{*}{405} \\
\hline PAX6 exon-5 R & TGGGGGGGTCCATAATTAGCA & & \\
\hline PAX6 exon-6 F & TCCAAGTGCTGGACAATCAA & \multirow[t]{2}{*}{707} & \multirow[t]{2}{*}{707} \\
\hline PAX6 exon-6 R & AGAGGACACAGACTAAGAGACA & & \\
\hline PAX6 exon-7 F & GGTGTATCTGCAAATCCACCCA & \multirow[t]{2}{*}{470} & \multirow[t]{2}{*}{470} \\
\hline PAX6 exon-7 R & CAATGTGGTCGATGTGTCCCA & & \\
\hline PAX6 exon-8 F & AAGGCTGACAGTTACCTTGGGAA & \multirow[t]{2}{*}{398} & \multirow[t]{2}{*}{398} \\
\hline PAX6 exon-8 R & TCTTCTATGCAAAGGGCCCTG & & \\
\hline PAX6 exon-9 F & TTGGTTGGAGGTAATGGGAGTG & \multirow[t]{2}{*}{334} & \multirow[t]{2}{*}{334} \\
\hline PAX6 exon-9 R & TGGCAGCAGAGCATTTAGCAG & & \\
\hline PAX6 exon 10-11 F & CCTAGAGACAGAGGTGCTTGTA & \multirow[t]{2}{*}{614} & \multirow[t]{2}{*}{614} \\
\hline PAX6 exon 10-11 R & GCAGACACAGCCAATGAGG & & \\
\hline PAX6 exon-12F & AGCTCGAGGCCCAATCTTAGAT & \multirow[t]{2}{*}{436} & \multirow[t]{2}{*}{436} \\
\hline PAX6 exon-12 R & AGGGACAAGGAAAGCAAGGAGT & & \\
\hline PAX6 exon-13 F1 & CTITCCTITGGATTGGGGTG & \multirow[t]{2}{*}{654} & \multirow[t]{2}{*}{-} \\
\hline PAX6 exon-13 R1 & CACAGATCAAACATCCATCCAGTC & & \\
\hline PAX6 exon-13 F2 & CCTATAAATTTGTATTCCATGTC & \multirow[t]{2}{*}{ Only used for sequencing } & 149 \\
\hline PAX6 exon-13 R2 & CTTGGCCAGTATTGAGACATATC & & \\
\hline SOSTDC1 exon-1 F & ACAAGTGATGAAGTCCAACTCT & 550 & 550 \\
\hline SOSTDC1 exon-1 R & TGTGAGCTAATGCTACCAGAA & & \\
\hline SOSTDC1 exon-2 F1 & TGAAAGTGTCCCTATACTATCC & 842 & 842 \\
\hline SOSTDC1 exon-2 R1 & AACTACAGGATACGTGGAAT & & \\
\hline SOSTDC1 exon-2 F2 & AAATTCCACGTATCCTGTAG & 800 & 800 \\
\hline SOSTDC1 exon-2 R2 & CATGTTAGAGGCAACAACA & & \\
\hline FAM2OB exon-1 $\mathrm{F}$ & GTCCTGCTGCTTGGCTGCCTACCTAC & 832 & 832 \\
\hline FAM20B exon-1 R & CCTTCAGCCGCGACCGCACA & & \\
\hline FAM2OB exon-2 F & ACTGCTGCCATCATTAGGTCC & 949 & 949 \\
\hline FAM2OB exon-2 R & CAGTGGGTTACCAGGTGTTCT & & \\
\hline FAM2OB exon-3 F & AATCAGGCTTGCTAATGGGTG & 417 & 417 \\
\hline FAM2OB exon-3 R & AGGCCAGAAATGAAATGACCTA & & \\
\hline FAM2OB exon-4F & TTAATTGCTCTGTGGGCTTAG & 825 & 825 \\
\hline FAM2OB exon-4 R & CACCTGCTTTCACCATCACTA & & \\
\hline FAM20B exon 5-6 F & AGAGTGAGACTGGGTAGAAAGGA & 1130 & 1130 \\
\hline FAM20B exon 5-6 R & TAGCCAAGAAAGAACGATGTAG & & \\
\hline FAM2OB exon $-7 \mathrm{~F}$ & AAGTTCTCCCTITGGTCTGTG & 561 & 561 \\
\hline $2 B$ exon-7 R & गाGGG] & & \\
\hline
\end{tabular}


Table 1 Amplification and sequencing primers (Continued)

\begin{tabular}{|c|c|c|c|}
\hline $\mathrm{ID}$ & Primer sequences & Amplicon size (bp) & Sequencing size (bp) \\
\hline FAM20B exon-8 F1 & CCATAATTTAACTATTTCCCAGTCG & 862 & 862 \\
\hline FAM2OB exon-8 R1 & CCAATCCCAGTATTCATCTATCC & & \\
\hline FAM2OB exon-8 F2 & TGGTGACGGGACAGAGTGGC & 795 & 795 \\
\hline FAM2OB exon-8 R2 & CAGTTGCTITGTTAATTTGGGAAG & & \\
\hline FAM2OB exon-8 F3 & AATTTCCACCTCTGCCTITAA & 793 & 793 \\
\hline FAM2OB exon-8 R3 & AGATGAGTGGGCACATCAGG & & \\
\hline FAM2OB exon-8 F4 & TGACTTTGCACCTAAGTAAATTCTG & 735 & 735 \\
\hline FAM2OB exon-8 R4 & GGTGGCTCATGCCTGTAATC & & \\
\hline FAM20B exon-8 F5 & CTGAACCCATGATGTTGTATTA & 666 & 666 \\
\hline FAM2OB exon-8 R5 & TCTTCCTATTGTCTCCTCCC & & \\
\hline FAM20B exon-8 F6 & TITAAGGCTACTCAGTGTTGTG & 842 & 842 \\
\hline FAM2OB exon-8 R6 & CTCCTGGATTCAAGTGATTCTCC & & \\
\hline FAM20B exon-8 F7 & AGGCAAATCTTGGAGAAAAC & 764 & 764 \\
\hline FAM2OB exon-8 R7 & TCTTGAATAATACTCTGAGCAAA & & \\
\hline FAM2OB exon-8 F8 & ATTTCCTGCCCTCCTCCAAC & 879 & 879 \\
\hline FAM2OB exon-8 R8 & CTACCTTGTCACCACCCAGA & & \\
\hline FAM20B exon-8 F9 & TAGTGTAAGGCTGCATTGTGG & 765 & 765 \\
\hline FAM2OB exon-8 R9 & CTTGAGGAATTGAAGGGAAA & & \\
\hline FAM2OB exon-8 F10 & CAGCGAATAACTACTGAGCAA & 514 & 514 \\
\hline FAM2OB exon-8 R10 & AAGGGAACTGAAATAGGAACCA & & \\
\hline
\end{tabular}

dental epithelium in mice results in supernumerary maxillary and mandibular incisors [15]. The deletion of Sclerostin domain-containing 1 (SOSTDC 1, also known as Wise, Ectodin, or USAG-1) in mice leads to the development of extra molar and incisors [16, 17]. However, research regarding the association between genetic polymorphism and mesiodens formation has been reported less often. Therefore, the purpose of the current study is to analyze the association between mesiodens formation and the genetic polymorphisms of genes related to this process, identifying the importance of genetic polymorphisms in mesiodens formation-related genes.

\section{Methods}

\section{Study participants}

One hundred patients (50 mesiodens group, 50 unrelated controls) were recruited in this study in Bengbu, China. The diagnosis of mesiodens was based on oral examination combined with periapical radiograph, panoramic radiograph, and/ or cone-beam computed tomography. The characteristics including gender, crown direction, the number of mesiodens, and the eruption status of mesiodens were recorded. All patients had no abnormalities in their head, ears, eyes, nose, throat, thyroid, trunk, or extremities and were without cleft lip or palate, congenital absence of teeth or tooth malformation. The family history was recorded.

\section{Saliva collection and genomic DNA extraction}

A total of $2 \mathrm{~mL}$ of unstimulated saliva sample for each recruited participant was collected and stored using Oragene DNA Self-Collection kits (Lang Fu, Shanghai, China). Genomic DNA was extracted using the MagBeads Saliva \& Swab DNA Extraction Kit (Regular \& Pre-loading Version, Enriching Biotechnology LTD, Shanghai, China) according to the manufacturer's protocol. The Genomic DNA samples were stored at $-20^{\circ} \mathrm{C}$ until further analysis.

\section{Sanger sequencing of selected mesiodens formation related genes}

We were particularly interested in PAX6, SOSTDC1, and $F A M 20 B$, which were reported to result in the formation of mesiodens. All exons and exon/intron boundaries of these three genes in 100 samples were amplified using a GC-rich PCR Kit (Sangon Biotech, Shanghai, China) combined with Champagne Taq DNA Polymerase (Vazyme, Nanjing, China). The PCR products were purified using a MagBeads Gel DNA Extraction Kit (Enriching Biotechnology LTD, Shanghai, China) according to the manufacturer's instructions. The PCR reaction mixture $(50 \mu \mathrm{L})$ included $3 \mu \mathrm{L}$ of template, $5 \mu \mathrm{L}$ of buffer, $4 \mu \mathrm{L}$ of dNTP, $1 \mu \mathrm{L}$ of each of the specific forward and reverse primers for these three genes, $0.25 \mu \mathrm{L}$ rTaq enzyme, and RNase-free water. The PCR was performed with the 
following temperature procedures: denaturation at $94^{\circ} \mathrm{C}$ for $5 \mathrm{~min}, 35$ cycles of $30 \mathrm{~s}$ at $94^{\circ} \mathrm{C}, 30 \mathrm{~s}$ at $55^{\circ} \mathrm{C}$, and $30 \mathrm{~s}$ at $72{ }^{\circ} \mathrm{C}$, with a 10 -min extension step at $72^{\circ} \mathrm{C}$. The purified products were used for Sanger sequenced using the ABI Prism 3730 platform (Applied Biosystems ${ }^{\mathrm{Tw}}$, USA). The primers used for amplification and sequencing are listed in Table 1 . The primers of PAX6 were selected according to previous study [18]. The amplification sequences were detailed in Additional file 1 and Additional file 2.

\section{Statistics}

The association between susceptibility to mesiodens and the genetic polymorphism of PAX6, SOSTDCland FAM20B were assessed using IBM SPSS 20.0 software (IBM, Armonk, NY, USA). The data were analyzed using pearson chi-square test with theoretical frequency $\geq 5$. For theoretical frequency less than 5 but at least 1 $(\leq 20 \%$ cell), the data were analyzed by continuity correction. For the rest, Fisher's Exact test was used. A $P$-value $<0.05$ was considered statistically significant. The relationships between the characteristics of mesiodens and the polymorphisms with $P$ value less than 0.05 were further analyzed using the same method described previously.

\section{Results}

\section{Basic characteristics of patients with mesiodens}

Four of the 50 patients with mesiodens (8\%) patients had a family history of mesiodens. The basic characterizes of mesiodens are listed in Table 2.

\section{Associations between mesiodens formation and genetic polymorphisms}

Considering the specific role of family history in mesiodens is still unknown, hence, careful family history is record in our study and excluded when we analyzed the association between mesiodens formation and gene polymorphisms. Removing patients with family history, three polymorphisms (rs750093295, rs667773 and rs3026393) were detected in PAX6. Two polymorphisms (rs6945425 and rs12699799) were detected in SOSTDC1. Twenty-nine polymorphisms (chr1:179025841, rs193196190, rs72707294, rs1024965514, rs745360443, rs778968805, rs2025584, rs140751029, rs9726948, rs16853612, rs9725887, rs9725888, rs4652352, rs147003645, rs72709441, rs4652353, rs4652354, rs56006430, rs3766625, rs3766626, rs775951319, rs16853619, rs2018786, rs16853621, rs188554154, rs530920451, rs9249, rs117216397, rs1220) were detected in FAM20B. Although, the $\mathrm{T}$ allele of $F A M 20 B$ (rs3766626) appears to be associated with mesiodens after removing unqualified sequencing results $(P=0.051)$. There were no significant differences of PAX6/SOSTDC1/FAM2OB gene polymorphisms between the two groups (Table 3 ). The distribution on
Table 2 Characteristic of patients with mesiodens, mean $\pm S D$, or $\mathrm{n}(\%)$

\begin{tabular}{ll}
\hline Numbers & 50 \\
\hline Age (years) & $11.8 \pm 9.3$ \\
Gender & \\
Females & $16(32.00)$ \\
$\quad$ Males & $34(68.00)$ \\
Number of mesiodens per patient & \\
1 & $35(70.00)$ \\
2 & $15(30.00)$ \\
Growth status & \\
1 erupted & $13(26.00)$ \\
1 impacted & $22(44.00)$ \\
1 erupted and 1 impacted & $8(16.00)$ \\
2 erupted & $2(4.00)$ \\
2 impacted & $5(10.00)$ \\
Crown direction & \\
1 vertical & $13(26.00)$ \\
1 horizontal & $4(8.00)$ \\
1 inverted & $17(34.00)$ \\
1 inverted and 1 vertical & $6(12.00)$ \\
1 horizontal and 1 vertical & $4(8.00)$ \\
2 vertical & $4(8.00)$ \\
1 horizontal and 1 inverted & $1(2.00)$ \\
Family history & $1(2.00)$ \\
Located in maxilla & $4(8.00)$ \\
\hline & $49(98.00)$ \\
& $1(2.00)$ \\
\hline
\end{tabular}

genotype of these markers according to gender, the number of mesiodens, crown direction, and the eruption status are listed in Tables 4 and 5 . The $\mathrm{T}$ allele of $F A M 20 B$ (rs3766626) was associated with susceptibility to two mesiodens $(P<0.001 ; \mathrm{OR}=8.333 ; \mathrm{CI}=2.516-27.600)$.

\section{Discussion}

A total of $8 \%$ of patients have a family history of mesiodens, which may indicate that the occurrence of mesiodens is partially determined by genetics. The patients with mesiodens were mostly concentrated in the northern and southern regions of Bengbu. The occurrence of mesiodens might have regional distribution characteristics.

PAX6 is an important gene involved in a series of diseases including eye diseases, diabetes, autism spectrum disorder and mesiodens [14, 19-21]. Variants of PAX6 are correlated with eye diseases and the insulin response [22-24]. Lei $\mathrm{HH}$ et al. identified that variants of rs667773 and rs3026393, and showed that the GG 
Table 3 The gene polymorphisms in patients with mesiodens and controls

\begin{tabular}{|c|c|c|c|c|}
\hline Marker & Gene polymorphism & Mesiodens & Controls & $P$ value \\
\hline \multirow{2}{*}{$\begin{array}{l}\text { rs2025584 } \\
\text { (FAM20B) }\end{array}$} & $\mathrm{AA} / \mathrm{AG} / \mathrm{GG}$ & 4/23/16 & 10/24/15 & 0.326 \\
\hline & $A / G$ & $31 / 55$ & $44 / 54$ & 0.223 \\
\hline \multirow{2}{*}{$\begin{array}{l}\text { rs140751029 } \\
\text { (FAM2OB) }\end{array}$} & $\mathrm{CC} / \mathrm{CT}$ & $40 / 4$ & $43 / 4$ & 1.000 \\
\hline & $\mathrm{C} / \mathrm{T}$ & $84 / 4$ & $90 / 4$ & 1.000 \\
\hline \multirow{2}{*}{$\begin{array}{l}\text { rs9726948 } \\
\text { (FAM20B) }\end{array}$} & GG/GT & $41 / 2$ & $41 / 6$ & 0.270 \\
\hline & $\mathrm{G} / \mathrm{T}$ & $84 / 2$ & $88 / 6$ & 0.282 \\
\hline \multirow{2}{*}{$\begin{array}{l}\text { rs16853612 } \\
\text { (FAM20B) }\end{array}$} & $\mathrm{AA} / \mathrm{AG} / \mathrm{GG}$ & 23/12/8 & $28 / 16 / 3$ & 0.206 \\
\hline & $A / G$ & $58 / 28$ & $72 / 22$ & 0.171 \\
\hline \multirow{2}{*}{$\begin{array}{l}\text { rs9725887 } \\
\text { (FAM20B) }\end{array}$} & $\mathrm{CC} / \mathrm{CT} / \mathrm{TT}$ & $15 / 22 / 6$ & 14/19/15 & 0.146 \\
\hline & $C / T$ & $52 / 34$ & $47 / 49$ & 0.120 \\
\hline \multirow{2}{*}{$\begin{array}{l}\text { rs9725888 } \\
\text { (FAM20B) }\end{array}$} & $\mathrm{CT} / \mathrm{TT}$ & $2 / 41$ & $6 / 42$ & 0.273 \\
\hline & $C / T$ & $2 / 84$ & $6 / 90$ & 0.284 \\
\hline \multirow{2}{*}{$\begin{array}{l}\text { rs4652352 } \\
\text { (FAM20B) }\end{array}$} & $\mathrm{AA} / \mathrm{AC} / \mathrm{CC}$ & $5 / 15 / 23$ & $6 / 12 / 30$ & 0.584 \\
\hline & $\mathrm{A} / \mathrm{C}$ & $25 / 61$ & $24 / 72$ & 0.537 \\
\hline \multirow{2}{*}{$\begin{array}{l}\text { rs147003645 } \\
\text { (FAM20B) }\end{array}$} & GG/AG & $43 / 0$ & $47 / 1$ & 1.000 \\
\hline & $\mathrm{G} / \mathrm{A}$ & $86 / 0$ & $95 / 1$ & 1.000 \\
\hline \multirow{2}{*}{$\begin{array}{l}\text { rs } 72709441 \\
\text { (FAM20B) }\end{array}$} & $\mathrm{CC} / \mathrm{TT} / \mathrm{CT}$ & $22 / 6 / 15$ & 28/3/17 & 0.477 \\
\hline & $C / T$ & $59 / 27$ & $73 / 23$ & 0.262 \\
\hline \multirow{2}{*}{$\begin{array}{l}\text { rs4652353 } \\
\text { (FAM2OB) }\end{array}$} & GG/GT/TT & $6 / 14 / 23$ & $6 / 12 / 30$ & 0.668 \\
\hline & $\mathrm{G} / \mathrm{T}$ & $26 / 60$ & $24 / 72$ & 0.430 \\
\hline \multirow{2}{*}{$\begin{array}{l}\text { rs4652354 } \\
\text { (FAM20B) }\end{array}$} & $\mathrm{CC} / \mathrm{CT} / \mathrm{TT}$ & 19/22/1 & $18 / 23 / 7$ & 0.146 \\
\hline & $\mathrm{C} / \mathrm{T}$ & $60 / 24$ & $59 / 37$ & 0.159 \\
\hline \multirow{2}{*}{$\begin{array}{l}\text { rs56006430 } \\
\text { (FAM20B) }\end{array}$} & $\mathrm{CC} / \mathrm{CG} / \mathrm{GG}$ & $7 / 15 / 21$ & $3 / 17 / 29$ & 0.269 \\
\hline & $C / G$ & $29 / 57$ & $23 / 75$ & 0.123 \\
\hline \multirow{2}{*}{$\begin{array}{l}\text { rs3766626 } \\
\text { (FAM20B) }\end{array}$} & $\mathrm{GG} / \mathrm{GT} / \mathrm{TT}$ & $16 / 21 / 4$ & $14 / 19 / 14$ & 0.067 \\
\hline & $\mathrm{G} / \mathrm{T}$ & $53 / 29$ & $47 / 47$ & 0.051 \\
\hline \multirow{2}{*}{$\begin{array}{l}\text { rs3766625 } \\
\text { (FAM20B) }\end{array}$} & $\mathrm{AA} / \mathrm{AG} / \mathrm{GG} / \mathrm{CC}$ & $6 / 15 / 20 / 0$ & $2 / 17 / 27 / 1$ & 0.277 \\
\hline & $\mathrm{A} / \mathrm{G} / \mathrm{C}$ & $27 / 55 / 0$ & $21 / 71 / 2$ & 0.131 \\
\hline \multirow{2}{*}{$\begin{array}{l}\text { rs16853619 } \\
\text { (FAM20B) }\end{array}$} & $A G / G G$ & $2 / 39$ & $6 / 41$ & 0.276 \\
\hline & $\mathrm{A} / \mathrm{G}$ & $2 / 80$ & $6 / 88$ & 0.287 \\
\hline \multirow{2}{*}{$\begin{array}{l}\text { rs72707294 } \\
\text { (FAM20B) }\end{array}$} & GG/GC/CC & 8/18/22 & $3 / 18 / 27$ & 0.249 \\
\hline & $\mathrm{G} / \mathrm{C}$ & $34 / 62$ & $24 / 72$ & 0.116 \\
\hline \multirow{2}{*}{$\begin{array}{l}\text { rs2018786 } \\
\text { (FAM20B) }\end{array}$} & $\mathrm{AA} / \mathrm{AG} / \mathrm{GG}$ & $7 / 14 / 23$ & $1 / 18 / 30$ & 0.061 \\
\hline & $A / G$ & $28 / 60$ & 20/78 & 0.076 \\
\hline \multirow{2}{*}{$\begin{array}{l}\text { rs16853621 } \\
\text { (FAM2OB) }\end{array}$} & $\mathrm{AA} / \mathrm{AG} / \mathrm{GG}$ & $36 / 4 / 1$ & $40 / 8 / 0$ & 0.361 \\
\hline & $A / G$ & $76 / 6$ & $88 / 8$ & 0.802 \\
\hline \multirow{2}{*}{$\begin{array}{l}\text { rs188554154 } \\
\text { (FAM2OB) }\end{array}$} & $\mathrm{GG} / \mathrm{GT}$ & $43 / 0$ & $47 / 1$ & 1.000 \\
\hline & $\mathrm{G} / \mathrm{T}$ & $86 / 0$ & $95 / 1$ & 1.000 \\
\hline \multirow{2}{*}{$\begin{array}{l}\text { rs530920451 } \\
\text { (FAM20B) }\end{array}$} & AA/AG & $43 / 1$ & $47 / 1$ & 1.000 \\
\hline & $A / G$ & $87 / 1$ & $95 / 1$ & 1.000 \\
\hline $\begin{array}{l}\text { rs } 775951319 \\
\text { (FAM20B) }\end{array}$ & $\mathrm{CC}$ & 41 & 47 & - \\
\hline \multirow{2}{*}{$\begin{array}{l}\text { rs778968805 } \\
\text { (FAM2OB) }\end{array}$} & $\mathrm{CC} / \mathrm{CT}$ & $46 / 0$ & $46 / 1$ & 1.000 \\
\hline & $\mathrm{C} / \mathrm{T}$ & $92 / 0$ & $93 / 1$ & 1.000 \\
\hline
\end{tabular}

Table 3 The gene polymorphisms in patients with mesiodens and controls (Continued)

\begin{tabular}{|c|c|c|c|c|}
\hline Marker & Gene polymorphism & Mesiodens & Controls & $P$ value \\
\hline \multirow{2}{*}{$\begin{array}{l}\text { rs } 745360443 \\
\text { (FAM2OB) }\end{array}$} & $\mathrm{GG} / \mathrm{AG}$ & $47 / 1$ & $49 / 0$ & 0.495 \\
\hline & $\mathrm{G} / \mathrm{A}$ & $95 / 1$ & $98 / 0$ & 0.495 \\
\hline \multirow{2}{*}{$\begin{array}{l}\text { rs } 1024965514 \\
\text { (FAM2OB) }\end{array}$} & $\mathrm{CT} / \mathrm{CC}$ & $1 / 47$ & $0 / 48$ & 1.000 \\
\hline & $C / T$ & $95 / 1$ & $96 / 0$ & 1.000 \\
\hline \multirow{2}{*}{$\begin{array}{l}\text { chr1:179025841 } \\
\text { (FAM20B) }\end{array}$} & $\mathrm{AA} / \mathrm{AG}$ & $45 / 1$ & $42 / 0$ & 1.000 \\
\hline & $A / G$ & $91 / 1$ & $84 / 0$ & 1.000 \\
\hline $\begin{array}{l}\text { rs193196190 } \\
\text { (FAM20B) }\end{array}$ & GG & 40 & 38 & - \\
\hline \multirow{2}{*}{$\begin{array}{l}\text { rs9249 } \\
\text { (FAM2OB) }\end{array}$} & $\mathrm{AA} / \mathrm{AG} / \mathrm{GG}$ & $5 / 16 / 23$ & $3 / 17 / 28$ & 0.666 \\
\hline & $A / G$ & $26 / 62$ & $23 / 73$ & 0.392 \\
\hline \multirow{2}{*}{$\begin{array}{l}\text { rs117216397 } \\
\text { (FAM20B) }\end{array}$} & $\mathrm{AA} / \mathrm{AG}$ & $42 / 2$ & $48 / 0$ & 0.226 \\
\hline & $A / G$ & $86 / 2$ & $96 / 0$ & 0.227 \\
\hline \multirow{2}{*}{$\begin{array}{l}\text { rs1220 } \\
\text { (FAM20B) }\end{array}$} & $\mathrm{AA} / \mathrm{AC} / \mathrm{CC} / \mathrm{GG}$ & 20/19/4/1 & $17 / 23 / 8 / 0$ & 0.428 \\
\hline & $\mathrm{A} / \mathrm{C} / \mathrm{G}$ & $59 / 27 / 2$ & $57 / 39 / 0$ & 0.126 \\
\hline \multirow{2}{*}{$\begin{array}{l}\text { rs667773 } \\
\text { (PAX6) }\end{array}$} & $\mathrm{CC} / \mathrm{CT} / \mathrm{TT}$ & $27 / 13 / 2$ & $36 / 10 / 1$ & 0.451 \\
\hline & $C / T$ & $67 / 17$ & $82 / 12$ & 0.178 \\
\hline \multirow{2}{*}{$\begin{array}{l}\text { rs750093295 } \\
\text { (PAX6) }\end{array}$} & $\mathrm{CC} / \mathrm{GG} / \mathrm{CT}$ & $41 / 1 / 0$ & $45 / 0 / 1$ & 0.730 \\
\hline & $C / T / G$ & $82 / 0 / 2$ & $91 / 1 / 0$ & 0.226 \\
\hline \multirow{2}{*}{$\begin{array}{l}\text { rs3026393 } \\
\text { (PAX6) }\end{array}$} & GG/GT/TT & $6 / 26 / 10$ & $17 / 20 / 10$ & 0.056 \\
\hline & $\mathrm{G} / \mathrm{T}$ & $38 / 46$ & $54 / 40$ & 0.104 \\
\hline \multirow{2}{*}{$\begin{array}{l}\text { rs6945425 } \\
\text { (SOSTDC1) }\end{array}$} & $A G / G G$ & $6 / 36$ & $8 / 38$ & 0.691 \\
\hline & $\mathrm{A} / \mathrm{G}$ & $6 / 78$ & $8 / 84$ & 0.704 \\
\hline \multirow{2}{*}{$\begin{array}{l}\text { rs12699799 } \\
\text { (SOSTDC1) }\end{array}$} & $\mathrm{AA} / \mathrm{AG} / \mathrm{GG}$ & $6 / 23 / 13$ & $8 / 17 / 22$ & 0.199 \\
\hline & $A / G$ & $35 / 49$ & $33 / 61$ & 0.369 \\
\hline
\end{tabular}

genotype of rs302693 was less prevalent in 20 patients with mesiodens than in 31 controls [18]. These results were further supported by our study. Polymorphisms in rs667773 and rs3026393 of PAX6 were detected in the current study, and the mesiodens group might have fewer genotypes of GG (rs3026393) than do the controls. Polymorphisms related to other diseases were not detected in this study; however, this may be because the patients with mesiodens did not have any other diseases.

Mesiodens is the most common type among supernumerary teeth, and the development of supernumerary teeth is closely associated with bone morphogenetic protein $(B M P)$ and Wnt signaling pathways [25]. $B M P$ is

Table 4 The distribution of AA genotype of FAM2OB (rs2018786) according to eruption status

\begin{tabular}{llllll}
\hline genotype & 1 erupted & 1 impacted & $\begin{array}{l}1 \text { erupted } \\
+1 \text { impacted }\end{array}$ & 2 erupted & 2 impacted \\
\hline AA & 1 & 3 & 0 & 0 & 3 \\
others & 8 & 17 & 8 & 2 & 2 \\
\hline
\end{tabular}


Table 5 The distribution of AA genotype of FAM20B (rs2018786) according to crown direction

\begin{tabular}{|c|c|c|c|c|c|c|c|c|}
\hline genotype & 1 vertical & 1 horizontal & 1 inverted & 1 inverted +1 vertical & 1 horizontal +1 vertical & 2 vertical & 1 horizontal+ 1 inverted & 2 inverted \\
\hline$\overline{A A}$ & 2 & 0 & 2 & 0 & 2 & 0 & 1 & 0 \\
\hline others & 8 & 3 & 14 & 5 & 2 & 4 & 0 & 1 \\
\hline
\end{tabular}

required for $S H H$ expression during early tooth development and postnatal root development [26]. However, SOSTDC1 is an inhibitor of $B M P$, and the deletion of SOSTDC1 in mice induces the formation of mesiodens [15]. Wnt, another signaling pathway, can be inhibited by SOSTDC1, located in the upstream of Sonic hedgehog (Shh), and induces the expression of Shh, followed by the induction of high SOSTDC1 expression. Insufficient SOSTDC1 enhances WNT signaling, which increases proliferation and continuous development of vestigial tooth buds and results in the formation of supernumerary teeth $[27,28]$. In our study, two polymorphisms (rs6945425 and rs12699799) were detected in SOSTDC1, but none of them were found related to susceptibility to mesiodens.

FAM20B is a member of Family with sequence similarity 20 (Fam20) proteins containing FAM20A, FAM20B, and FAM20C in the human genome [29]. $F A M 20 A$ knockout mice have biomineralization defects, and mutations in FAM20A have been found to be associated with amelogenesis imperfecta subsequently [30-32]. FAM20B null mice showed mesiodens [15]; however, the relationship between variants of FAM2OB and mesiodens has not yet been reported. Our results suggest for the first time that individuals with $\mathrm{T}$ allele of FAM20B (rs3766626) appear to have a low risk of mesiodens, which was located in the $3^{\prime}$ untranslated region ( $3^{\prime}$ UTR) of corresponding gene. Although it isn't translated into protein, previous and recent studies showed that variant in 3' UTR region could impact the expression of mRNA [33, 34].

The current study provides information on the association between genetic polymorphisms and the occurrence of mesiodens; however, there are some limitations. The sample size (mainly the control size) and the number of genes analyzed in this study were limitations. The mechanism by which these polymorphism affect mesiodens is unknown. Further studies including more samples, more genes, and the mechanism of these polymorphism on mesiodens are needed.

\section{Conclusions}

There were no significant differences of PAX6/SOSTDC1/ $F A M 20 B$ gene polymorphisms between the two groups. Further studies with large samples on T allele of FAM20B (rs3766626) are needed.

\section{Additional files}

Additional file 1: The amplification sequences of FAM2OB. (DOCX $22 \mathrm{~kb}$ ) Additional file 2: The amplification sequences of SOSTDC1. (DOCX $13 \mathrm{~kb}$ )

\section{Abbreviations}

AXIN2: Axin 2; BMP: Bone morphogenetic protein; ENAM: Enamelin; Fam20: Family with sequence similarity member 20; GREM2: Gremiln-2; PAX6: Paired box gene 6; SOSTDC 1: Sclerostin domain-containing 1; UTR: Untranslated region

\section{Acknowledgements}

Not applicable

\section{Authors' contributions}

KZ and SSL conceived and designed the experiments; JCL and JCX contributed to the data acquisition; SKL, YFC, RXZ and RXT analyzed the data; SSL wrote the manuscript; KZ revised the manuscript. All authors read and approved the final manuscript.

\section{Funding}

This study was funded by Education Department of Anhui Province, China (No. KJ2013Z203). The funding body helped with the data collection, sequencing and analysis.

\section{Availability of data and materials}

The data and materials of the present study were available from the corresponding author.

\section{Ethics approval and consent to participate}

This study was approved by the Ethics Committee of [2017] KY010 by the First Affiliated Hospital of Bengbu Medical College. Informed consents were written before recruitment. Written informed consent for participation under 16 years old in the study was obtained from their parent or guardian.

\section{Consent for publication}

Not applicable.

\section{Competing interests}

The authors declare that they have no conflict of interest.

Received: 10 August 2018 Accepted: 20 May 2019

Published online: 27 May 2019

\section{References}

1. Van Buggenhout G, Bailleul-Forestier I. Mesiodens. Eur J Med Genet. 2008; 51:178-81.

2. Colak H, Uzgur R, Tan E, Hamidi MM, Turkal M, Colak T. Investigation of prevalence and characteristics of mesiodens in a non-syndromic 11256 dental outpatients. Eur Rev Med Pharmacol Sci. 2013;17:2684-9.

3. Nagaveni NB, Sreedevi B, Praveen BS, Praveen Reddy B, Vidyullatha BG, Umashankara KV. Survey of mesiodens and its characteristics in 2500 children of Davangere city, India. Eur J Paediatr Dent. 2010;11:185-8.

4. Ayers $E$, Kennedy D, Wiebe C. Clinical recommendations for management of mesiodens and unerupted permanent maxillary central incisors. Eur Arch Paediatr Dent. 2014;15(6):421-8.

5. Gündüz K, Celenk $P$, Zengin Z, Sümer $P$. Mesiodens: a radiographic study in children. J Oral Sci. 2008;50(3):287-91.

6. Meighani G, Pakdaman A. Diagnosis and management of supernumerary (mesiodens): a review of the literature. J Dent (Tehran). 2010;7:41-9. 
7. De Oliveira Gomes C, Drummond SN, Jham BC, Abdo EN, Mesquita RA. A survey of 460 supernumerary teeth in Brazilian children and adolescents. Int J Paediatr Dent. 2008;18:98-106.

8. Kim Y, Jeong T, Kim J, Shin J, Kim S. Effects of mesiodens on adjacent permanent teeth: a retrospective study in Korean children based on conebeam computed tomography. Int J Paediatr Dent. 2018;28(2):161-9.

9. Gomes RR, Fonseca JAC, Paula LM, Acevedo AC, Mestrinho HD. Dental anomalies in primary dentition and their corresponding permanent teeth. Clin Oral Investig. 2004;18:1361-7

10. Gerreth K, Zaorska K, Zabel M, Borysewicz-Lewicka M, Nowicki M. Association of ENAM gene single nucleotide polymorphisms with dental caries in polish children. Clin Oral Investig. 2016;20:631-6.

11. Zhang ZS. Association between COX2 -765G/C polymorphism and periodontitis in Chinese population: a meta-analysis. BMC Oral Health. 2018;18(1):32

12. Haddaji Mastouri M, De Coster P, Zaghabani A, Jammali F, Raouahi N, Ben Salem A, Saad A, Coucke P. H'mida Ben Brahim D. genetic study of nonsyndromic tooth agenesis through the screening of paired box 9 , msh homeobox 1, axin 2, and Wnt family member 10A genes: a case-series. Eur J Oral Sci. 2018;126:24-32.

13. Mostowska A, Biedziak B, Zadurska M, Bogdanowicz A, Olszewska A, Cieślińska K, Firlej E, Jagodziński PP. GREM2 nucleotide variants and the risk of tooth agenesis. Oral Dis. 2018;24:591-9.

14. Kriangkrai R, Chareonvit S, Yahagi K, Mm F, Eto K, Iseki S. Study of Pax6 mutant rat revealed the association between upper incisor formation and midface formation. Dev Dyn. 2006;235:2134-43.

15. Tian Y, Ma P, Liu C, Yang X, Crawford DM, Yan W, Bai D, Qin C, Wang X. Inactivation of Fam20B in the dental epithelium of mice leads to supernumerary incisors. Eur J Oral Sci. 2015;123:396-402.

16. Kassai Y, Munne P, Hotta Y, Penttilä E, Kavanagh K, Ohbayashi N, Takada S, Thesleff I, Jernvall J, Itoh N. Regulation of mammalian tooth cusp patterning by ectodin. Science. 2005;309:2067-70.

17. Munne PM, Tummers M, Järvinen E, Thesleff I, Jernvall J. Tinkering with the inductive mesenchyme: Sostdc1 uncovers the role of dental mesenchyme in limiting tooth induction. Development. 2009;136:393-402.

18. Lei HH, Liu H, Ge LH. PAX6 polymorphisms in 20 Chinese children with supernumerary teeth in the maxillary incisor area. Int J Paediatr Dent. 2011; 21:271-7.

19. Lim HT, Kim DH, Kim H. PAX6 aniridia syndrome: clinics, genetics, and therapeutics. Curr Opin Ophthalmol. 2017;28:436-47.

20. Mitchell RK, Nguyen-Tu MS, Chabosseau P, Callingham RM, Pullen TJ, Cheung R, Leclerc I, Hodson DJ, Rutter GA. The transcription factor Pax6 is required for pancreatic $\beta$ cell identity, glucose-regulated ATP synthesis, and Ca2+ dynamics in adult mice. J Biol Chem. 2017;292:8892-906.

21. Kikkawa T, Casingal CR, Chun SH, Shinohara H, Hiraoka K, Osumi N. The role of Pax6 in brain development and its impact on pathogenesis of autism spectrum disorder. Brain Res. 2018. S0006899318301112.

22. Thomas S, Thomas MG, Andrews C, Chan WM, Proudlock FA, McLean RJ, Pradeep A, Engle EC, Gottlob I. Autosomal-dominant nystagmus, foveal hypoplasia and presenile cataract associated with a novel PAX6 mutation. Eur J Hum Genet. 2014;22:344-9.

23. Liang CL, Hsi E, Chen KC, Pan YR, Wang YS, Juo SH. A functional polymorphism at 3'UTR of the PAX6 gene may confer risk for extreme myopia in the Chinese. Invest Ophthalmol Vis Sci. 2011;52:3500-5.

24. Ahlqvist E, Turrini F, Lang ST, Taneera J, Zhou Y, Almgren P, Hansson O, Isomaa B, Tuomi T, Eriksson K, Eriksson JG, Lyssenko V, Groop L. A common variant upstream of the PAX6 gene influences islet function in man. Diabetologia. 2012;55:94-104.

25. Lu X, Yu F, Liu J, Cai W, Zhao Y, Zhao S, Liu S. The epidemiology of supernumerary teeth and the associated molecular mechanism. Organogenesis. 2017;13:71-82.

26. Li J, Feng J, Liu Y, Ho TV, Grimes W, Ho HA, Park S, Wang S, Chai Y. BMPSHH signaling network controls epithelial stem cell fate via regulation of its niche in the developing tooth. Dev Cell. 2015;33:125-35.

27. Ahn Y, Sanderson BW, Klein OD, Krumlauf R. Inhibition of Wht signaling by wise (Sostdc1) and negative feedback from Shh controls tooth number and patterning. Development. 2010;137:3221-31.

28. Kim YY, Hwang J, Kim HS, Kwon HJ, Kim S, Lee JH, Lee JH. Genetic alterations in mesiodens as revealed by targeted next-generation sequencing and gene co-occurrence network analysis. Oral Dis. 2017;23:966-72.
29. Zhang H, Zhu Q, Cui J, Wang Y, Chen MJ, Guo X, Tagliabracci VS, Dixon JE, Xiao J. Structure and evolution of the Fam20 kinases. Nat Commun. 2018;9: 1218.

30. O'Sullivan J, Bitu CC, Daly SB, Urquhart JE, Barron MJ, Bhaskar SS, MartelliJúnior H, dos Santos Neto PE, Mansilla MA, Murray JC, Coletta RD, Black GC, Dixon MJ. Whole-exome sequencing identifies FAM20A mutations as a cause of amelogenesis imperfecta and gingival hyperplasia syndrome. Am J Hum Genet. 2011;88:616-20.

31. Jaureguiberry G, De la Dure-Molla M, Parry D, Quentric M, Himmerkus N, Koike T, Poulter J, Klootwijk E, Robinette SL, Howie AJ, Patel V, Figueres ML, Stanescu HC, Issler N, Nicholson JK, Bockenhauer D, Laing C, Walsh SB, DA MC, Povey S, Asselin A, Picard A, Coulomb A, Medlar AJ, Bailleul-Forestier I, Verloes A, Le Caignec C, Roussey G, Guiol J, Isidor B, Logan C, Shore R, Johnson C, Inglehearn C, Al-Bahlani S, Schmittbuhl M, Clauss F, Huckert M, Laugel V, Ginglinger E, Pajarola S, Spartà G, Bartholdi D, Rauch A, Addor MC, Yamaguti PM, Safatle HP, Acevedo AC, Martelli-Júnior H, dos Santos Netos PE, Coletta RD, Gruessel S, Sandmann C, Ruehmann D, Langman CB, Scheinman SJ, Ozdemir-Ozenen D, Hart TC, Hart PS, Neugebauer U, Schlatter E, Houillier P, Gahl WA, Vikkula M, Bloch-Zupan A, Bleich M, Kitagawa H, Unwin RJ, Mighell A, Berdal A, Kleta R. Nephrocalcinosis (enamel renal syndrome) caused by autosomal recessive FAM20A mutations. Nephron Physiol. 2012;122:1-6.

32. Wang SK, Aref P, Hu Y, Milkovich RN, Simmer JP, El-Khateeb M, Daggag H, Baqain ZH, Hu JC. FAM20A mutations can cause enamel-renal syndrome (ERS). PLoS Genet. 2013;9(2):e1003302.

33. Hitomi $Y$, Ebisawa M, Tomikawa M, Imai T, Komata T, Hirota T, Harada M, Sakashita M, Suzuki Y, Shimojo N, Kohno Y, Fujita K, Miyatake A, Doi S, Enomoto T, Taniguchi M, Higashi N, Nakamura Y, Tamari M. Associations of functional NLRP3 polymorphisms with susceptibility to food-induced anaphylaxis and aspirin-induced asthma. J Allergy Clin Immunol. 2009; 124:779-85.

34. Knox B, Wang Y, Rogers LJ, Xuan J, Yu D, Guan H, Chen J, Shi T, Ning B, Kadlubar SA. A functional SNP in the 3'-UTR of TAP2 gene interacts with microRNA hsa-miR-1270 to suppress the gene expression. Environ Mol Mutagen. 2018;59:134-43.

\section{Publisher's Note}

Springer Nature remains neutral with regard to jurisdictional claims in published maps and institutional affiliations.

Ready to submit your research? Choose BMC and benefit from:

- fast, convenient online submission

- thorough peer review by experienced researchers in your field

- rapid publication on acceptance

- support for research data, including large and complex data types

- gold Open Access which fosters wider collaboration and increased citations

- maximum visibility for your research: over $100 \mathrm{M}$ website views per year

At BMC, research is always in progress.

Learn more biomedcentral.com/submissions 